CZU:81'373.43

https://doi.org/10.52505/filomod.2021.15.24

\title{
CONSIDERAT,II PRIVIND FENOMENUL NEOLOGIEI ÎN TERMINOLOGIE
}

\author{
Natalia GOBJILA \\ Universitatea de Stat din Moldova
}

\begin{abstract}
Rezumat. Diseminarea rapidă a evoluțiilor științifice și tehnologice, introducerea noilor concepte sociale și economice și comunicarea permanentă în diverse domenii de specialitate condiționează apariția constantă a unui număr de termeni noi. Neologismele terminologice rezultă din necesitatea numirii unice a noilor concepte pentru care nu există un model sau precedent lingvistic sub forma unui model autohton. Lucrarea urmărește studierea fenomenului începând de la conturarea noțiunilor de neologie și neologism și continuând prin prezentarea rolului acestora în terminologie, criteriile de determinare a unităților neologice, clasificarea neologismelor, precum și caracteristicile prin care neologismele terminologice se deosebesc de cele lexicale, astfel examinându-se modul în care acest fenomen este perceput din perspectiva terminologiei si limbajelor specializate.
\end{abstract}

Cuvinte-cheie: neologie, neologism, terminologie, termen, concept, desemnare.

Abstract. The rapid dissemination of scientific and technological developments, the introduction of new social and economic concepts and the communication in various specialized fields determine the constant emergence of new terms. Terminological neologisms result from the need for the unique naming of new concepts for which there is no linguistic model or precedent in the form of a local pattern. The paper aims at studying the phenomenon, starting from outlining the notions of neology and neologism, and continuing by presenting their role in terminology, criteria for determining neological units, classification of neologisms, and the characteristics by which terminological neologisms differ from lexical ones, thus examining the way in which neology is perceived from the perspective of terminology and specialized languages.

Keywords: neology, neologism, terminology, term, concept, designation.

Neologismele terminologice rezultă din necesitatea numirii unice a noilor concepte pentru care nu există un model sau precedent lingvistic sub forma unui model autohton. Nu există o metodă unică pentru formarea neologismelor; sunt folosite mai multe procese destul de distincte. Neologismele pot fi clasificate în două tipuri: fie sunt creații cu totul noi ce sunt extrem de rare în majoritatea limbilor, fie sunt împrumuturi din alte limbi (Sager, 1997, p. 38).

Maria Teresa Cabré, Rosa Estopà Bagot și Chelo Vargas Sierra susțin că diseminarea rapidă a evoluțiilor științifice și tehnologice, introducerea noilor 
concepte sociale și economice și comunicarea permanentă în diverse domenii de specialitate necesită apariția constantă a unui număr de termeni noi. Prin urmare, limbile trebuie să își actualizeze terminologia în același ritm în care au loc aceste schimbări sociale.

Astfel, această actualizare continuă a lexicului apare ca urmare a creării de noi concepte într-o limbă sau din importul acestora de către o comunitate de vorbitori. Este posibil să observăm mai multe situaţii care necesită noi termeni: a) este descoperită sau inventată o nouă entitate care trebuie numită; b) într-un context de traducere poate apărea necesitatea de selectare sau creare a unui echivalent pentru un termen în textul sursă care până acum a existat doar în limba care a creat termenul sau c) în contextul planificării lingvistice instituțiile trebuie să stabilească termenii cei mai potriviți prin adoptarea sau adaptarea unui împrumut sau prin propunerea unei noi formațiuni.

În aceste contexte există două abordări diferite în ceea ce privește neologia: pe de o parte crearea unui neologism original, iar pe de altă parte selecția terminologică sau înlocuirea unui termen original. Juan C. Sager a numit prima abordare neologie primară, iar a doua neologie secundară sau de traducere. Distincția dintre neologia primară și cea secundară este fundamentală în clasificarea neologismelor de specialitate în două grupuri mari: cele care apar în limbi împreună cu apariția noilor concepte și cele care apar în procesele de transfer de cunoștințe între diferite comunități de vorbitori.

Trei contribuții importante la clasificarea neologismelor sunt: în primul rând, distincția dintre neologia generală și neologia de specialitate, numită de Guy Rondeau neonimie sau neologie terminologică de alți autori precum Maria Teresa Cabré sau John Humbley; în al doilea rând, neologia denominativă, numită și neologie referențială, și neologia stilistică de către Louis Guilbert sau neologie expresivă de Maria Teresa Cabré, prima fiind în special legată de terminologie, iar a doua de comunicare. Și în al treilea rând, distincția dintre neologia spontană și neologia planificată propusă de Jean-Claude Boulanger (Cabré, Estopà Bagot, Vargas Sierra, 2012, p. 1-2).

Maria Teresa Cabré observă că distingerea unui neologism nu este un proces simplu, deoarece trebuie luate în considerare anumite aspecte care sunt într-o anumită măsură arbitrare. Astfel, există câțiva parametri posibili pentru a determina dacă o unitate poate fi calificată drept neologism sau nu:

a. diacronia: o unitate constituie un neologism dacă a apărut recent;

b. lexicografia: o unitate constituie un neologism dacă nu este înregistrat în dicționare;

c. instabilitatea sistematică: o unitate constituie un neologism dacă prezintă semne de instabilitate formală (morfologică, grafică, fonetică) sau instabilitate semantică;

d. psihologia: o unitate constituie un neologism dacă este percepută de către vorbitori ca fiind una nouă. 
Aceste criterii care nu se exclud reciproc nu dau aceleași rezultate și nici nu pot fi aplicate în aceleași contexte. Neologii tind să favorizeze parametrul lexicografic ca fiind cel mai sistematic pentru a determina dacă o unitate lexicală este un neologism sau nu. În conformitate cu acest criteriu, un termen este un neologism dacă nu apare în corpusul lexicografic ales ca corpus de referință, cunoscut și sub denumirea de corpus de excludere. Acest fapt modifică problema de la identificarea neologismelor la alegerea corpusului lexicografic de referință care variază nu numai în funcție de subiectul terminologiei, ci și de tipul de neologism, deoarece există mai multe tipuri diferite.

$\mathrm{O}$ clasificare a neologismelor nu poate fi bazată pe un singur criteriu, ci trebuie să fie multidimensională. Din punctul de vedere al apartenenței există o distincție între două mari grupuri de neologisme lexicale care se comportă diferit: cele prezente în limbajul general (neologisme adevărate) și cele prezente în limbajele specializate (cunoscute și sub numele de neonime). Ele diferă unele de altele în mai multe caracteristici: crearea, funcția lor principală, relația lor cu sinonimele contextuale, resursele favorizate pentru creare, continuarea existenței lor în limbă, modul în care coexistă în sistem, modul în care se raportează la alte sisteme.

Dacă e să comparăm neonimele sau neologismele terminologice cu neologismele lexicale, putem identifica următoarele diferențe:

1. neonimele apar din cauza necesității unei desemnări și sunt de obicei mai stabile, pe când neologismele lexicale sunt de obicei sunt mai spontane, adică apar fără un motiv aparent și, în general, au o existență de scurtă durată;

2. neonimele resping sinonimia, deoarece pot influența negativ eficiența comunicativă. În schimb, neologismele lexicale nu sunt afectate de sinonimie, ci de obicei coexistă cu sinonime și dobândesc o anumită valoare stilistică ca o caracteristică contrastantă;

3. multe neonime reprezintă sintagme, în timp ce neologismele lexicale au tendinţa spre concizie formală;

4. neonimele sunt concepute pentru a fi internaționale, multe fiind compuși bazați pe limbile neoclasice.

Spre deosebire de neologismele lexicale, neonimele sunt caracterizate de aceleași trăsături proprii termenilor: lipsă de ambiguitate, referință unică, apartenența la un domeniu de specialitate, stabilitate, conformitate cu modelele existente de formare a termenilor. În ciuda acestor diferențe, Maria Teresa Cabré susține că este dificil să separăm clar cele două tipuri (Cabré, 1999, p. 205-206).

Deși noțiunea este prezentă în dicționare de mult timp, o primă încercare serioasă de definire a unui neologism a fost efectuată în 1975 de Alain Rey. Rey prezintă o discuție despre ce este un cuvânt, tipurile de neologisme pe care le putem distinge (formal, semantic și pragmatic) și ce înseamnă pentru 
un cuvânt să fie „,nou”. În ceea ce privește acest ultin aspect, Alain Rey ajunge la concluzia că nu se pot oferi criterii solide și obiective pentru a măsura ce înseamnă a fi nou și, prin urmare, noțiunea de neologism este doar un indiciu al unui sentiment subiectiv. Opinia lui poate fi egalată cu parametrul psihologic propus de Maria Teresa Cabré (Jannsen, 2006, p. 2).

În ceea ce privește criteriile utilizate la formarea neologismelor, Elisa Mattiello menționează existența a șapte astfel de criterii, și anume:

1. transparența: noile formațiuni lexicale care apar trebuie să fie transparente din punct de vedere fonologic, morfologic și semantic;

2. regularitatea: producerea neologismelor trebuie să se conformeze cu modele de formare a cuvintelor și restricțiilor impuse de acestea, această conformitate fiind explicată de presiunea de a respecta paradigmele existente, fiind mai puțin probabil ca formele neregulate să devină instituționalizate în cadrul comunității de vorbitori;

3. productivitatea: majoritatea formațiunilor noi se bazează pe modele curente de productivitate lingvistică;

4. decodificarea: dacă decodificarea unui neologism este considerată dificilă, există tendința de a furniza suficient material contextual pentru dezambiguizarea acestuia, precum și diverse modalități de marcaj metalingvistic;

5. informativitatea: formarea unui neologism duce la reducerea volumului de informație transmisă din cauza restricționării la un număr mai mic de părți constitutive;

6. efectul mnemonic: utilizarea unor strategii de formarea a neologismelor care ar facilita memorizarea acestora;

7. analogia: conform lui Lamb, principiul analogiei este poate explica abilitatea vorbitorilor de a interpreta o formațiune nouă prin substituirea părților componente în unitățile deja cunoscute utilizate drept exemple (Mattiello, 2017, p. 28-29).

În concluzie, neologismele terminologice sau neonimele rezultă din necesitatea de desemnarea a unui nou concept, de alegere a unui echivalent în procesul de traducere, sau adoptarea sau adaptarea unui împrumut în contextul planificării lingvistice. Neonimele se deosebesc de neologismele lexicale în unele aspecte, fiind caracterizate de aceleași trăsături proprii termenilor.

\section{Referințe bibliografice:}

1. CABRÉ, Maria Teresa. Terminology: Theory, Methods, and Applications. Amsterdam/Philadelphia: John Benjamin Publishing Company, 1999. 249 p.

2. CABRÉ, Maria Teresa, ESTOPÀ BAGOT, Rosa, VARGAS SIERRA, Chelo. Neology in specialized communication. In: Terminology. International Journal of 
Theoretical and Applied Issues in Specialized Communication. Amsterdam/Philadelphia: John Benjamin Publishing Company, 2012, vol. 18, nr. 1, p. 1-8.

3. JANNSEN, Maarten. Orthografic Neologisms: Selection Criteria and SemiAutomatic Detection. 2006, [online] Disponibil: http://maarten.janssenweb.net/Papers/ neologisms.pdf [citat 24.09.2021].

4. MATTIELLO, Elisa. Analogy in Word-formation: A Study of English Neologisms and Occasionalisms. Berlin: Walter de Gruyter GmbH \& Co, 2017, 247 p.

5. SAGER, Juan C. Term Formation. În: WRIGHT, Sue Ellen, BUDIN, Gerhard (eds.) Handbook of Terminology Management. Vol. 1 Basic Aspects of Terminology Management. Amsterdam/Philadelphia: John Benjamin Publishing Company, 1997, p. 25-41. 